\title{
THE PROLOGUE TO THE APOSTOLIC TRADITION OF HIPPOLYTUS.
}

THE credit of being the first to identify the 'Egyptian Church Order' as the Apostolic Tradition of Hippolytus belongs to Baron Eduard von der Goltz. As long ago as 1906 he wrote an article in the Sitzungsberichte der königlich preussischen Akademie der Wissenschaften, entitled 'Unbekannte Fragmente altchristlicher Gemeindeordnungen nach G. Horners englischer Ausgabe des äthiopischen Kirchenrechtsbuchs', in which he drew attention to the passages contained in the Ethiopic version of the $\mathrm{EgCO}$ which are not found in the other versions. Later in the same year he devoted a longer essay, in the Zeitschrift filr Kirchengeschichte (Heft i), to a special study of the baptismal forms which appear on pp. 162-1 78 of Mr Horner's Statutes of the Apostles ('Die Taufgebete Hippoiyts und andere Taufgebete der alten Kirche'). In both articles he examined the Prologue to the $\mathrm{Eg} \mathrm{CO}$ which is preserved in the Latin and Ethiopic versions (and in an altered form in the Apostolic Constitutions viii 3 ), and declared it to be the opening passage of the Apostolic Tradition of Hippolytus, recognizing at the same time that the eighth book of the Ap. Const. (cc. $3 \mathrm{ff}$ ) and the 'Canons of Hippolytus' are collateral derivatives of the Apostolic Tradition. He therefore anticipated the results of Prof. Ed. Schwartz by four years. Writing in 19ro, Schwartz had not seen the two articles just mentioned; and I remained in ignorance of them till November 1920 , when Baron E. von der Goltz very kindly sent me copies of them. As I could not refer to the articles in my essay in 'Texts and Studies' viii 4 (1916), I take the opportunity of calling attention to them which the present occasion affords.

The Prologue to the Apostolic Tradition contains the key to the identification of the document which it introduces; but its text as preserved in the Verona Latin and Ethiopic versions is not free from difficulty, and in more than one place the author's meaning is open to doubt. Fortunately we get some further light on the Prologue from a somewhat unexpected quarter. This fresh evidence bas, indeed, been available for a considerable time, though it is only within the last couple of years that I have become aware of it. It is possible that some one else may already have noticed it and brought it to bear, but so far I have not seen any reference to it. It deserves to be taken into account by future editors of this important document.

In $1913 \mathrm{M}$. F. Nau published a French translation of the collection of documents which is known as the Octateuch of Clement, and which 
is preserved in a Syriac version. The collection is composed of the following pieces : books $i$ and $i$ are the two books of the Testament of the Lord; book iii is the document called the Apostolic Church Order or the Ecclesiastical Canons; book iv contains the first two chapters (those on charismata) of the eighth book of the Apostolic Constitutions ; books v-vii answer to other parts of the same eighth book of the Ap. Const.; and book viii contains the Apostolic Canons.

The purpose of this Note is to draw attention to a passage in the Octateuch the peculiar interest of which escaped the notice of $\mathbf{M}$. Nau when making his translation.

The fifth book of the Octateuch comprises those chapters of Ap. Const. viii which treat of ordinations, with omission of the liturgy which follows the ordination of a bishop. It opens with ch. 3, which is an adaptation of the Prologue to the Apostolic Tradition. But here a surprise awaits us. The compiler of the Octateuch, like the person who made the 'Epitome' of Ap. Const. viii, usually follows his source without other alteration than the omission of matter which he does not require. It is true that the Epitomist broke this rule twice, once in the ordination form for a bishop, by substituting the original prayer of Hippolytus for the enlarged formula of Ap. Const., and again by making a similar substitution in regard to the ordination of the lectordepartures from the rule-of-thumb method of simple excerption which have given untold trouble to students of these documents in our day. Now at the beginning of his fifth book of Clement the maker of the Octateuch has been guilty of the same sort of inconsistency, but with a difference: he gives us neither exactly what the 'Constitutor' made of the Prologue of Hippolytus nor exactly what Hippolytus wrote, but a combination of the two-he interpolates the Ap. Const. text by recourse to Hippolytus himself.

M. Nau's translation of the Octateuch was made from the text of Cod. syr. 148 of the Borgian collection, which until 1902 was kept in the Propaganda library, but has since been removed to the Vatican. I have recently obtained photographs of a part of this MS, and can now give the Syriac text of the passage mentioned above. I add a Latin translation, which is as literal as I could make it, and which at any rate keeps the order of the Syriac words unchanged. I have used Latin because I found it impossible to turn the passage quite literally into English; but I have avoided as far as possible using the words of the old Latin version. The text of the Verona Latin and that of Ap. Const. viii 3 are printed side by side with that of the Octateuch.

1 La version syriaque de COctateuque de Climent traduite en franfais, Paris, Lethielleux. 
Cod. Borg. syr. 148 foll. 91 b-92 a.

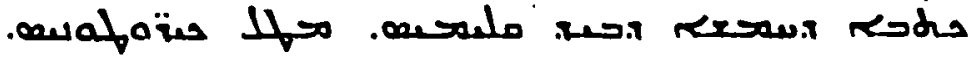

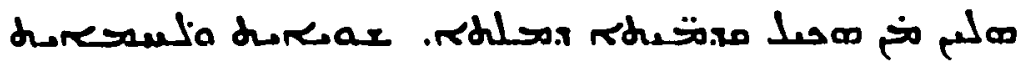

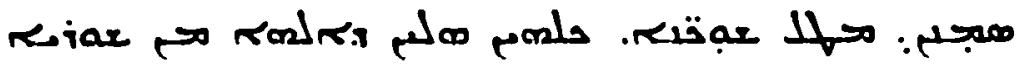

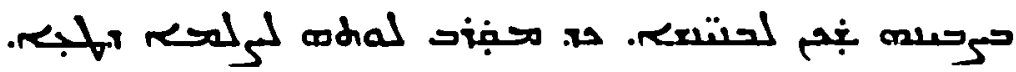

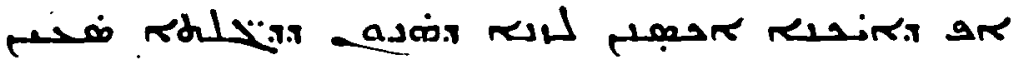

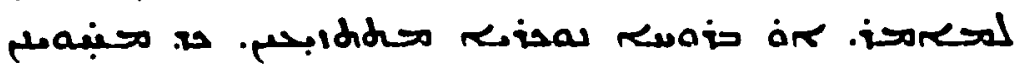

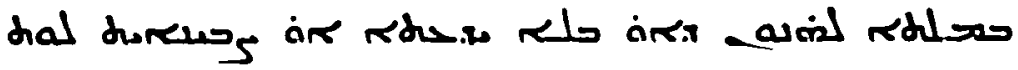

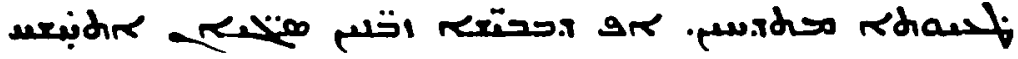

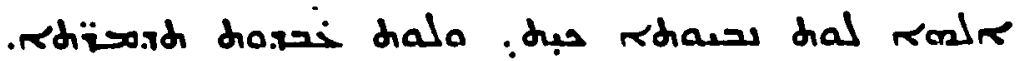

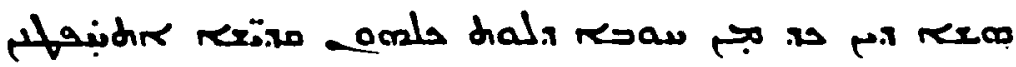

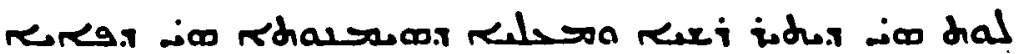

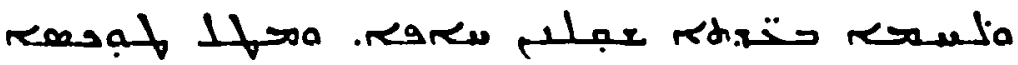
rododo

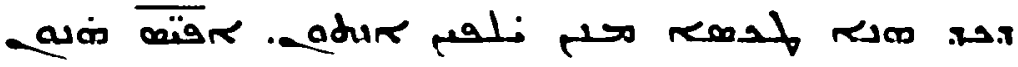

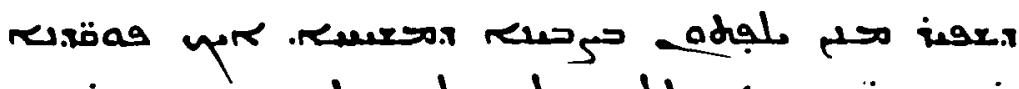

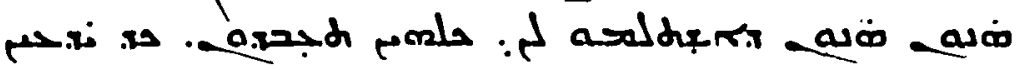
ol. adur

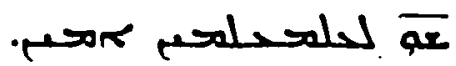

Verona Latin.

Ap. Const. vïi 3 .

\section{Octatenel.}

Liber quintus per Clementom. De Chirotonits.

(a) Ea quidem quae verba (or verbi) fuerunt digne posuimus de donationibus, quanta quidem Deus a principio secundum propriam voluntatem preestitit hominibus, offerens sibi eam imaginem quae aberraverat.

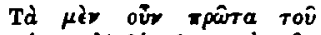

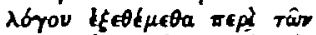

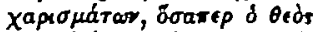

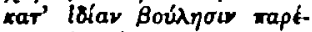

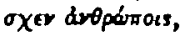

E2 denique priora verbi digne at congruenter posuimus de donis, ${ }^{1}$ quaecumque Deus ab initio sua voluntate donaverit hominibus, offerens sibi imaginem quae erraverat,

1 The word shukkane, which is not the common Syriac word for 'gifts', is apt as a rendering of Xapionara. The verb rendered 'donaverit', just below, is from the same root. 
Verona Latin.

(b)

(c) Nunc autem ex caritate quam in omnes sanctos habuit producti, ad verticem traditionis quae catecizat ad ecclesias perreximus, ut ii qui bene ducti (prob. docti) sunt eam quae permansit usque nunc traditionem exponentibus nobis custodiant,

(d) et agnoscentes firmiores maneant, propter eum qui nuper inventus est per ignorantiam lapsus vel error et hos qui ignorant: praestante sancto spiritu perfectam gratiam eis qui recte credunt, ut cognoscant quomodo oportet tradi et custodiri omnia cos qui ecclesize proesunt.
Ap. Const. viii 3.

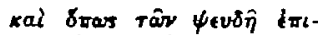
Xepoúrter $\lambda$ ( tpíp Treónati kivouperav

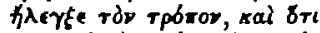

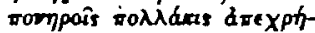

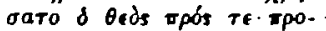
фiteíar kai тeparozatav.

vบvì $8 z$

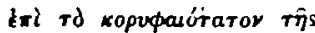

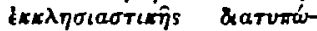

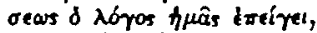

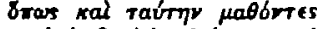

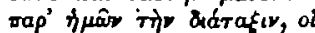

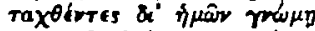

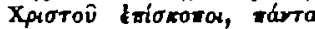
kardi Tds rapaboteloas $\hbar \mu \hat{i \nu}$

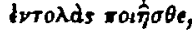

Odaterich.

sed et quomodo arguerimus modum corum qui mendacia audent dicere vel spiritu alieno moventur, ostendentes verbo eis, qui aut ignorantia aut voluntate ad errorem pelluntur, quod etiam malis saepenumero usus sit Deus ad prophetiam scilicet et ad faciend mira. cula.

Nunc autem imore enga omnes sanctas provocali, ad id quod magis principale et sublime est fidei, quae decons et congrious est in rodesiis, impetum acapimus; et de dispositione et constitutione ecclesiastica (ut loquamur) concitat nos verbum, ut hunc ordinem a nobis discentes, episcopi, qui bene a nobis didicistis, voluntate Christi, secundum mandata ista quae tradita sunt nobis omnia faciatis,

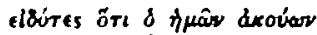

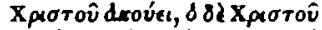
axoviar rov̂ $\theta \in o \hat{v}$ aitrov $\mathrm{kai}$. rerpds drovet, $\$ \hbar$ sofa els roùs alâras detiv. scientes quoniam qui nos audit (Christum audit, et qui Christum audit) Deum patrem eius audit; cui gloria in seccula saeculorum, amen.

The italics in the third column indicate correspondences on the part of the Octateuch text with the old Latin version which are not shared by the Ap. Const.-in other words, the interpolations into the latter drawn by the compiler of the Octateuch from the Prologue of Hippolytus. I add a few notes on this new text.

I. Double renderings of a single Greek word are common in Syriac 
translations, and we have several examples of them in the passage before us. Thus in (a) we find 'digne et congruenter' where the old Latin has only 'digne'; under $(c)$ we have 'magis principale et sublime' where Ap. Const. has кopuqauorarov and the old Latin 'verticem', and

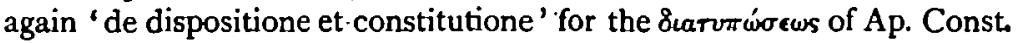
On 'decens et congruens' in the same section, see below.

2. The italics in $(a)$ shew unmistakably that the compiler of the Octateuch has used the Prologue of Hippolytus as a secondary source.

3. In (b) 'posuimus' is to be understood before 'sed et quomodo'; but 'arguerimus' for $\ddot{\eta} \lambda \in \gamma \xi e$ (sc. $\dot{o} \theta \in o ́ s$ ) is an error, perhaps of the Syriac translator.

4. The clause, in (b), 'ostendentes verbo eis, qui aut igmorantia aut voluntate ad errorem pelluntur' is an addition to the Ap. Const. text suggested by the Prologue at $(d)$, where we read of a 'nuper inventus ... per ignorantiam lapsus vel error'.

5. In (c) 'amore erga ommes sanctos provocati' is added from the Prologue, where the old Latin reads 'ex caritate quam in omnes sanctos habuit producti'. But the Syriac helps us to remove a difficulty in the Latin: it shews us that (as I had already suspected) the Latin translator misunderstood the Greek before him. What he read

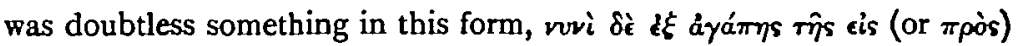

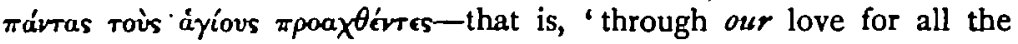
saints' (i.e. the faithful). This the sense requires, for the author would hardly have alleged God's love for the saints as his reason for treating of the apostolic tradition. The translator ought therefore to have supplied 'habemus', not 'habuit'.' We may compare Hippolytus

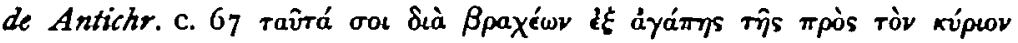

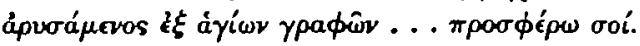

6. In (c) again the words of the Syriac 'fidei ... impetum accepimus' are additional to the Ap. Const. text and answer to 'traditionis quae catecizat ad ecclesias perreximus' of the Prologue, except that 'faith' has been substituted for 'tradition'. But 'the tradition which catechizes'. is an expression of the old Latin which is both odd in itself and difficult to fit into the sentence. In the Journal for April 1915 (xvi p. 330), Dr Frere suggested that the Latin translator 'may have mistaken $\kappa a \theta \eta^{\prime}$ '

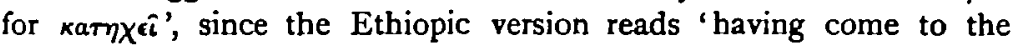
source of the proper tradition in the churches .8 The Syriac favours

1 I had suggested this correction to Dom Wilmart in 1918. See an article by him in Revue dw Clerge Francais, Oct. 15, 1918, p. 87 note 2. We may also compare

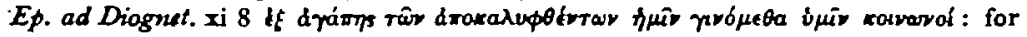
cc. $x i$ and rii of the Epistle, which have nothing to do with the rest, are now by a number of scholars, and I believe rightly, escribed to Hippolytus.

- This conjecture was made already by von der Goltz in 1906, Zeitschrift $f$. Kinchengesch. (Heft i p. 8) ' quae catecizat $=$ die sich gebuhrt = firs rabtjke oder «äijuova'. 
this conjecture, for 'quae decens et congruess est in ecclesiis' evidently contains another double rendering of a single Greek verb, and gives much the same sense as the Ethiopic. The expression 'impetum accepimus' (so literally) answers to 'perreximus'. of the old Latin:

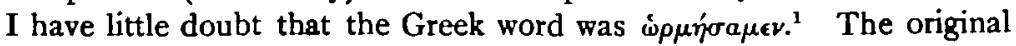
clause therefore may have run something in this way: kzi корифiेv $\hat{\eta} s$

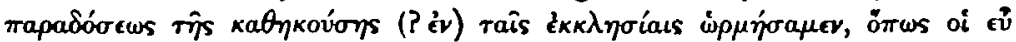

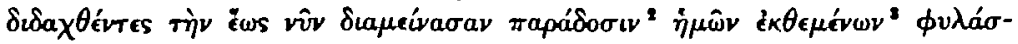
$\sigma \omega \sigma \dot{v}$.

7. The words "qui bene a nobis didicistis", substituted for the oi raxtévres of Ap. Const., seem to be inspired by the Prologue: 'ii qui bene ducti (more probably docti) sunt'. The rest of the passage follows Ap. Const., but with (apparently accidental) omission of the words which I have supplied in brackets.

R. H. Connolly.

\section{THE DE HABITU VIRGINUM OF ST CYPRIAN.}

The De Habitu Virginum, to give the homily its traditional title rather than that of $A d$ Virgines which is well attested by the Cheltenham List, is one of St Cyprian's earliest writings. It stands next to the Ad Donatum, the first of all, in the Cheltenham List, and has the same place in Pontius's Vita Cypriani $\S 7$, as also in all the most important groups of MSS. And not only is there nothing in the homily itself inconsistent with such a date, but much that suits better with it than with a later period. There are two certain points. It is the work of a bishop, for in $\S \mathbf{I}$ the writer expressly says that correction in the spirit of love is the office of fratres et maxime sacerdotes, i. e. bishops, and claims for his office, and therefore for his authority to reprove, that its existence is a proof of the fulfilment of a prophecy. Pastor is a terminus technicus for a bishop, and the words et dabo uobis pastores secundum cor meum, here, as elsewhere in Cyprian, are a literal statement that the

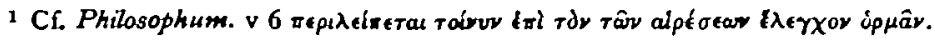

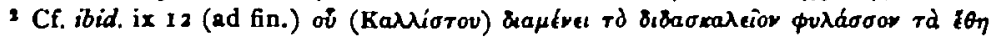

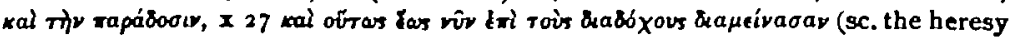

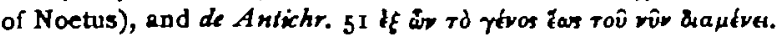

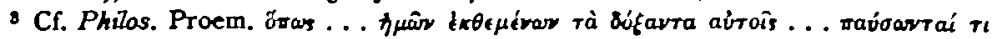

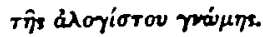

- The verb is equivalent to 'docti estis', as the passive, meaning ' to be taught', is not much used.

- A paper read before the Cambridge Theological Society in February 1904, and revised in accordance with some kind suggestions of Prof. C. H. Turner. 